\title{
THE RÔLE OF COLLOID AND OF SALINE IN THE TREATMENT OF SHOCK ${ }^{1,2}$
}

\author{
By A. W. WINKLER, T. S. DANOWSKI, AND J. R. ELKINTON \\ (From the Department of Medicine, Yale University School of Medicine, New Haven)
}

(Received for publication December 15; 1945)

The effects of intravenous saline in early saltdepletion shock in dogs have been described in previous reports $(1,2)$. Cardiac output and blood pressure recovered considerably or completely from their depressed levels, plasma volume rapidly reexpanded, and protein which had disappeared earlier returned to the circulating plasma. Intravenous glucose solutions were much less effective in correcting the depression in hemodynamic status and in restoring the deficit of circulating plasma protein. Since a deficit of plasma protein was an almost invariable accompaniment of acute salt-depletion shock, experiments were undertaken to determine whether the administration of serum or gelatin would produce a hemodynamic effect greater than that of saline alone.

\section{MATERIALS AND METHODS}

Adult fasting female dogs were used throughout. The methods by which salt depletion was induced and by which cardiac output, blood pressure, circulation time, relative plasma volume, and change in circulating plasma protein were measured have been described (1).

In 3 experiments essentially salt-free gelatin or serum was administered. ${ }^{3}$ In 4 experiments therapy consisted of the injection of 130 to $300 \mathrm{ml}$. of serum or gelatin solution containing 0.9 per cent sodium chloride. This procedure replaced only 11 to 36 per cent of the salt deficit. In 2 experiments serum or gelatin was immediately followed by the administration of 5.0 per cent sodium chloride solution, and in 1 experiment by 0.9 per cent sodium chloride solution, in amounts sufficient to replace the entire salt deficit.

1 The authors are indebted to Dr. Samuel Harvey and Dr. John Lockwood for the use of the Laboratories of the Department of Surgery.

2 Aided by a grant from the Fluid Research Fund, Yale University School of Medicine.

${ }^{8}$ Fresh pooled dog serum was dialyzed against 5 per cent glucose solution to lower the concentration of sodium chloride (Experiment 81B). The gelatin employed was Knox P20 prepared to contain either 0.12 per cent (Experiment 55L) or 0.9 per cent sodium chloride (Experiments $55 \mathrm{M}, 55 \mathrm{~N}$ ) and was obtained from the Knox Gelatin Company through the courtesy of Mr. D. Tourtellotte. In Experiment 55K, however, the low-salt gelatin was prepared in the same way as the low-salt serum.
The effects of 0.9 per cent saline solution in amounts equivalent to those present in experiments with undialyzed serum or gelatin were studied in 3 animals. The results obtained following the complete replacement of the salt losses with either 0.9 per cent or 5 per cent saline solutions alone are included in Figure 1. These have been taken from published data (2).

Data from control experiments reported elsewhere in which treatment was withheld for 2 to 3 hours are available in Figure 1 for purposes of comparison (2).

\section{RESULTS}

Administration of small amounts of 0.9 per cent saline solution or of low-salt serum or gelatin failed after 2 hours to improve the cardiovascular dynamics, or to restore the plasma volume and circulating plasma protein beyond the degree which was observed sporadically in animals without any treatment whatsoever (Figure 1. Columns $1,2,3$ ).

Infusion of similar amounts of either serum or gelatin containing a normal complement of salt, on the other hand, produced an essentially complete restoration of plasma volume and circulatory efficiency together with an increase of the circulating plasma protein considerably beyond the initial values (Figure 1, Column 4). It is significant that the amount of salt administered equalled only 11 to 36 per cent of the amount initially withdrawn.

The degree of recovery observed following the administration of small amounts of serum or gelatin containing salt could be reproduced by the infusion of 5 per cent or 0.9 per cent saline solutions in amounts equivalent to or greater than the initial salt deficits (Figure 1, Columns 5, 6).

Treatment with serum or gelatin together with complete restoration of the salt deficit produced no greater improvement in the circulatory statics and dynamics than that observed following colloid solutions with incomplete replacement of the previously withdrawn sodium chloride (Figure 1, Columns 7, 8). 


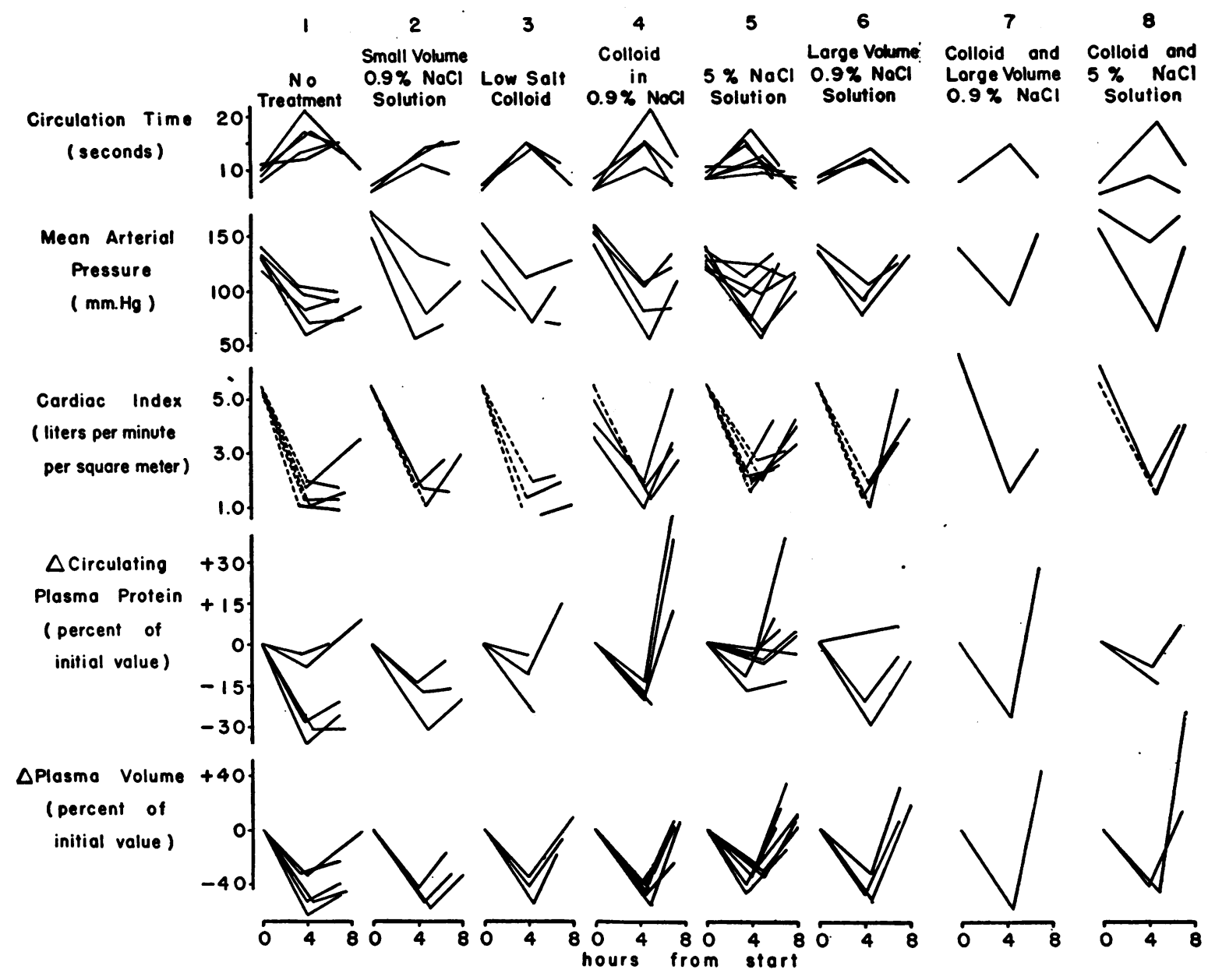

Fig. 1. Effects of Treatment of Salt-Depletion Shock With Solutions of Saline and of Colloid

Salt depletion was induced between the first and second points ( 0 and 3 to 5 hours). Immediately after the second point an infusion of one of the solutions indicated at the top of the chart was administered. In some experiments in which cardiac output was not determined before infusion of the salt solution, a broken line is drawn from the mean value previously reported in normal dogs (1). Data in columns 1, 5, and 6 are included from the preceding paper (2) for purposes of comparison.

\section{DISCUSSION}

Recent reviewers of the whole problem of shock, while recognizing that diminution of the plasma volume is but one factor in the chain of events involved in shock, have emphasized that it is a constant and important part of the chain ( 3 to 5). Although there is disagreement as to whether the loss of plasma protein is due to a generalized increase in capillary permeability (6), or to local capillary damage, nearly all students of the problem attribute the decrease in plasma volume to loss of plasma proteins. Experimental demonstration that the loss of plasma is commensurate with the accumulation of fluid containing plasma protein in the traumatized tissues rests upon the work of a number of investigators ( 7 to 9 ). Upon this premise have been based the major methods of treatment of traumatic, hemorrhagic, and burn shock involving the use of transfusions of whole blood, and infusions of plasma, and plasma fractions. Although it is known that mere restoration of blood volume may be completely ineffectual in the late stages of shock (10), much experimental and clinical evidence supports its efficacy in the earlier phases. Experimental studies indicating the superiority of collodial solutions, especially plasma, 
A. W. WINKLER, T. S. DANOWSKI, AND J. R. ELKINTON

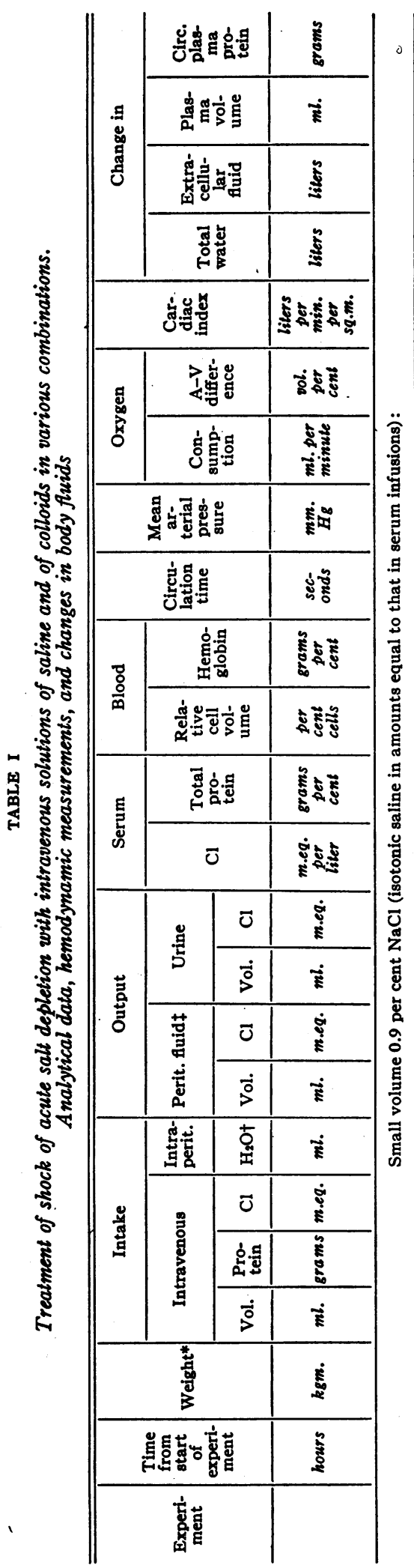

\begin{tabular}{|c|c|c|}
\hline oे & 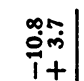 & 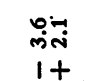 \\
\hline $\begin{array}{l}0 \\
\mathbb{Z} \\
+\end{array}$ & 品品 & 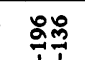 \\
\hline | & 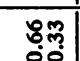 & ㅇํㄱ \\
\hline † & it & iq \\
\hline $\begin{array}{l} \\
0 \\
i \\
\end{array}$ & 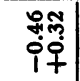 & 고ㅇㅝㅜ \\
\hline 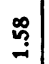 & 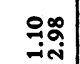 & חָָ \\
\hline$\stackrel{n}{\Xi}$ & 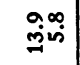 & $\begin{array}{l}\text { or } \\
\text { Iiv }\end{array}$ \\
\hline$\vec{a}$ & 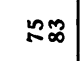 & 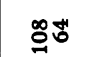 \\
\hline$\approx$ & 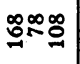 & 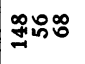 \\
\hline$a$ & 머묘 & מהזר \\
\hline$\dot{\dot{p}}$ & 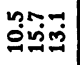 & 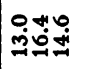 \\
\hline $\begin{array}{l}0 \\
\dot{b} \\
\dot{b}\end{array}$ & 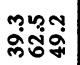 & 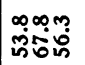 \\
\hline ָָּ & 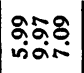 & 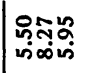 \\
\hline 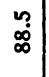 & 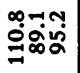 & 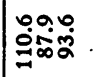 \\
\hline 3 & 00 & - \\
\hline \& & $\infty \infty$ & 00 \\
\hline 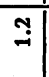 & 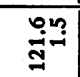 & 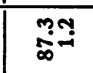 \\
\hline$\Xi$ & $=$ & 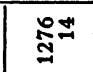 \\
\hline & 惫 & 串 \\
\hline$\stackrel{\infty}{=}$ & $\overline{\bar{j}}$ & 苛 \\
\hline 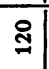 & 8 & do \\
\hline 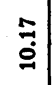 & శ్రా & $\mid \begin{array}{c}a=0 \\
\infty \\
\infty\end{array}$ \\
\hline & $\sin \infty$ & orto \\
\hline 莹 & 落 & $\infty$ \\
\hline
\end{tabular}

\begin{tabular}{|c|c|c|}
\hline $\begin{array}{c}\text { na } \\
\text { Nom } \\
1+\end{array}$ & $\left|\begin{array}{c}0 \\
i \\
1\end{array}\right|$ & $\begin{array}{l}0 \\
i \\
1\end{array}$ \\
\hline 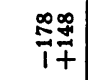 & 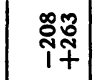 & 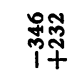 \\
\hline 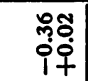 & 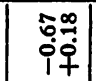 & 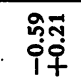 \\
\hline :0े & 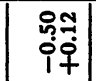 & $\begin{array}{l}\text { Fீत् } \\
\text { ił }\end{array}$ \\
\hline 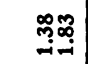 & : & 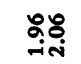 \\
\hline $\overrightarrow{\dot{g}} \overline{\mathrm{g}}$ & $\stackrel{\infty}{\hdashline}$ & $\stackrel{\infty-1}{=\infty}$ \\
\hline ఐంి & 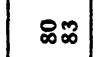 & $\cong$ \\
\hline$\stackrel{\infty}{\infty}$ & 으ㅇㅝㅠ & מ్ \\
\hline$m=$ & Nan & 표 \\
\hline 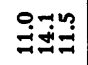 & Fing & 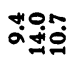 \\
\hline 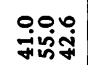 & 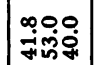 & 用我 \\
\hline 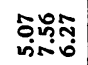 & 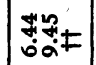 & 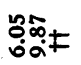 \\
\hline & 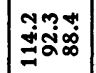 & 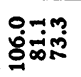 \\
\hline - & 00 & 00 \\
\hline$\infty 0$ & no & no \\
\hline 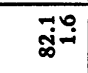 & 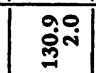 & 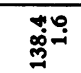 \\
\hline$\underset{\Xi}{-\infty}$ & ${ }_{n}^{R} \vec{N}$ & 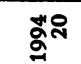 \\
\hline ఫ్త & 8 & 员 \\
\hline$\stackrel{\infty}{\infty}$ & 8 & $\stackrel{\infty}{+\infty}$ \\
\hline$\stackrel{8}{\circ}$ & $\begin{array}{ll}n \\
m \\
m\end{array}$ & $\stackrel{\circ}{\dot{\phi}}$ \\
\hline$\underline{\Xi}$ & 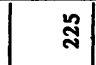 & 8 \\
\hline som & 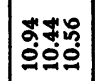 & 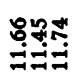 \\
\hline orn & - $++\infty$ & ong \\
\hline$\underset{\infty}{\infty}$ & 荺 & $\overrightarrow{\mathrm{H}}$ \\
\hline
\end{tabular}


RÔLE OF COLLOID AND OF SALINE IN TREATMENT OF SHOCK

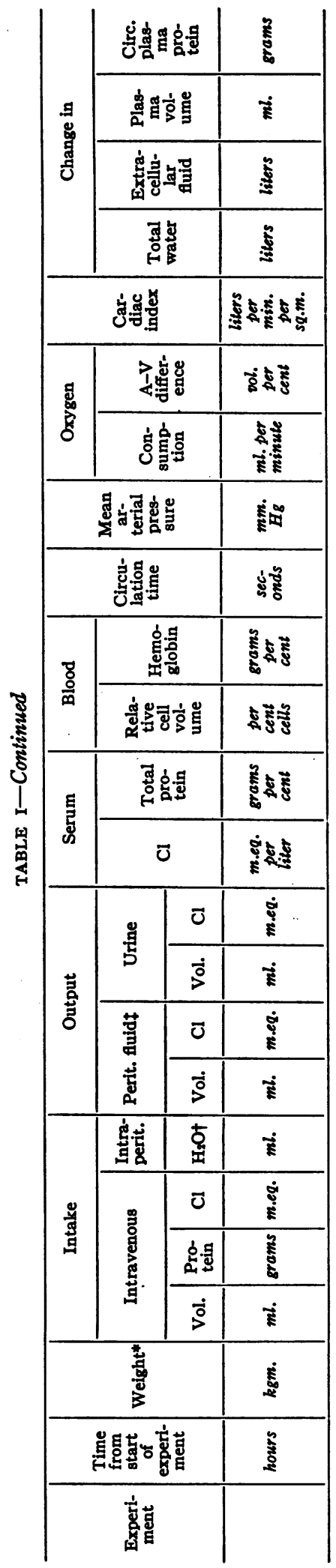

\begin{tabular}{|c|c|c|c|}
\hline 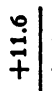 & 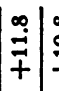 & $\begin{array}{c}\infty \\
\stackrel{0}{+} \\
\end{array}$ & $\begin{array}{l}\overrightarrow{0} \\
0 \\
1\end{array}$ \\
\hline$\stackrel{\tilde{m}}{\vec{t}}$ & $\stackrel{\infty}{+\infty}$ & \begin{tabular}{l}
$\infty$ \\
\multirow{+}{*}{} \\
\end{tabular} & 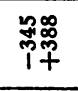 \\
\hline \begin{tabular}{c|} 
\\
$m$ \\
0 \\
$⿱ 亠 䒑$
\end{tabular} \mid & \begin{tabular}{|c|c|} 
& \\
0 & \\
$\vdots$ &
\end{tabular} & (דָ & $\begin{array}{l}\text { क्ष } \\
\text { iơ }\end{array}$ \\
\hline 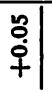 & $\mid \begin{array}{c}a \\
\dot{\phi} \\
+1\end{array}$ & 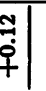 & ำ \\
\hline $\begin{array}{l}8 \\
\dot{m}\end{array}$ & $\mid \begin{array}{c}\text { : } \\
\dot{\infty}\end{array}$ & 怘 & 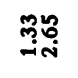 \\
\hline$\stackrel{?}{\sim}$ & $\vec{i}$ & is & nูo \\
\hline ఖ & $\approx$ & $\therefore$ & 8త్త \\
\hline$\infty$ & $\tilde{m}$ & 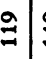 & 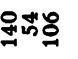 \\
\hline 인 & - & - & יה \\
\hline$\stackrel{m}{+}$ & 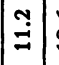 & $\begin{array}{l}\dot{0} \\
\dot{0}\end{array}$ & 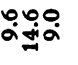 \\
\hline ज़्र & $\left|\begin{array}{l}0 \\
\vdots \\
\vdots\end{array}\right|$ & $\begin{array}{c}n \\
\substack{\infty \\
m}\end{array}$ & 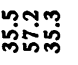 \\
\hline $\begin{array}{c}\infty \\
\stackrel{0}{0} \\
a\end{array}$ & $\mid$ & 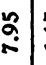 & 78 \\
\hline 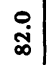 & à & 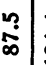 & 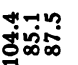 \\
\hline 0 & 0 & 0 & 我 \\
\hline 0 & 0 & in & ஜึ॰ \\
\hline 9 & $\mid \begin{array}{l}0 \\
-1\end{array}$ & 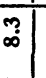 & ุำ \\
\hline \pm & 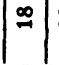 & $\boldsymbol{\infty}^{\prime}$ & 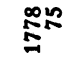 \\
\hline & & & $\underset{7}{8}$ \\
\hline$\stackrel{a}{\dot{m}}$ & $\left|\begin{array}{l}\vec{j} \\
\mid \dot{n}\end{array}\right|$ & 官 & $\dot{0}$ \\
\hline $\begin{array}{l}+1 \\
\infty\end{array}$ & $\left|\begin{array}{l|} \\
\dot{m}\end{array}\right|$ & $\Xi$ & $\stackrel{\circ}{\circ}$ \\
\hline 익 & $|\stackrel{p}{\infty}|$ & 8 & 8 \\
\hline $\begin{array}{l}\circ \\
\stackrel{0}{0} \\
\end{array}$ & 过 & 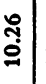 & 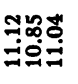 \\
\hline-1 & - & -1 & ons \\
\hline 意 & $\mid$ & $\stackrel{\infty}{\circ}$ & 离 \\
\hline
\end{tabular}
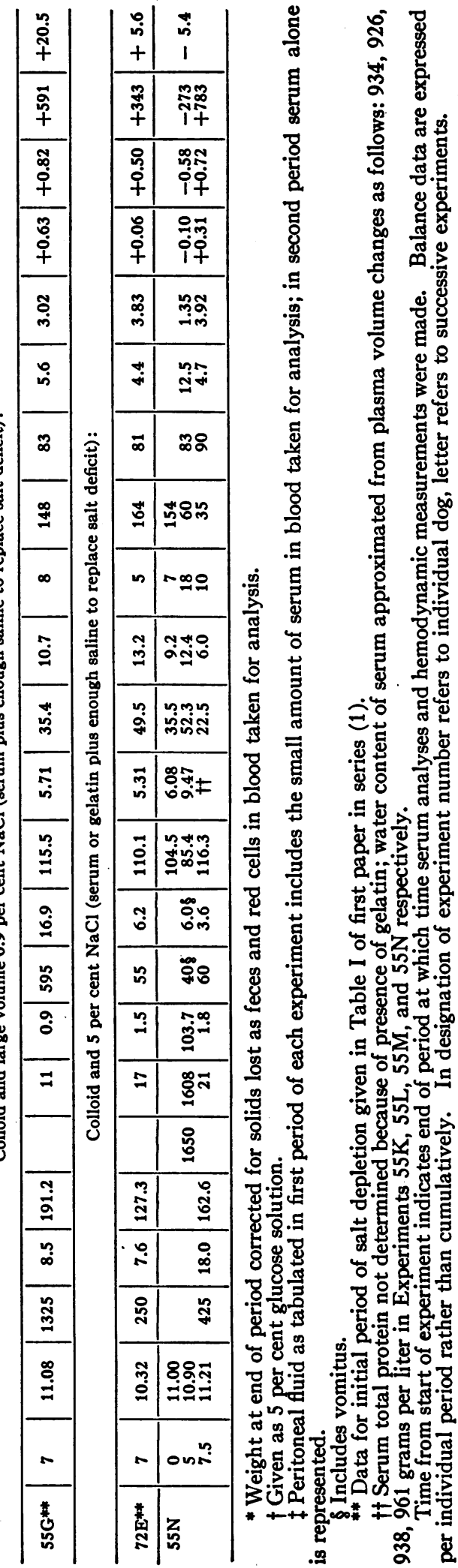
over crystalloid solutions (isotonic saline or glucose), in restoring plasma volume in traumatic shock go back to 1932 (11). Since then many other investigators have shown the same results in hemorrhagic, traumatic, and burn shock in animals, and in human subjects (12 to 17 ). The effectiveness of collodial solutions under these circumstances of plasma protein loss can hardly be doubted.

Recently the rôle of electrolytes, principally sodium, in the etiology and treatment of traumatic shock has been emphasized. It was found that plasma was as effective by mouth as it was by vein in the treatment of an early stage of shock induced in mice by thermal burns or by the release of a previously ligated limb $(18,19)$. These experiments were interpreted to indicate that the effect of plasma is mainly that of the saline which it contains. This theory was applied clinically in the treatment of burn shock by the oral administration of large volumes of isotonic sodium lactate (20). The patients so treated exhibited a large positive sodium balance during the first few days. Recent tissue analyses of mice subjected to burns and injected with radioactive sodium indicate that sodium was pooled in burned areas (21). These experiments support earlier work demonstrating that the fall of sodium in scalded cats could be prevented if the blood vessels to the injured area were occluded (22). On the basis of these studies it has been suggested (20) that the diminished plasma volume in burn and traumatic shock is due to a systemic sodium depletion, analogous to that produced experimentally by loss of electrolytes into the peritoneal cavity (23), rather than to a loss of circulating plasma protein.

One other finding has been cited to support the efficacy of saline infusions alone in traumatic shock; namely that in shock produced in dogs by ligation of a limb, the plasma volume could be maintained by the infusion of very large amounts of isotonic saline despite very low concentrations of plasma protein (24). These results were interpreted, however, as showing, not that a systemic sodium depletion was corrected, but that the loss of the colloid osmotic pressure of the plasma protein was counterbalanced by an increase in the hydrostatic pressure of the interstitial fluid.

Our own experiments may help resolve these differences in interpretation. They fully confirm the great therapeutic efficacy of salt restoration in early shock due to salt depletion. On the other hand, they demonstrate that solutions containing colloid can exert a beneficial effect in shock which cannot be ascribed solely to their salt content. Infusion of small amounts of colloid solution, containing only a fraction of the sodium chloride initially removed, produced a beneficial therapeutic effect indistinguishable from that which followed the complete replacement of the salt deficit with saline solution. This indicates clearly that the administration of colloid renders unnecessary the complete replacement of the salt deficit to bring the animal out of shock. Since this effect could not be obtained by giving the animal the equivalent of the salt present in the colloid, a definite rôle for colloid in the treatment of salt depletion shock is established. A synergism is manifested when salt and colloid are given together. This interpretation is further supported by the experiments in which small amounts of either low salt colloid or small amounts of physiological saline solution failed to produce the improvement which followed the injection of colloid containing 0.9 per cent sodium chloride.

Hence, even though it may be possible to demonstrate in certain types of shock the undeniable capacity of saline to restore complete circulatory efficiency, administration of colloid as well will provide a margin of safety. From the point of view of optimal therapy it is advisable to give both. The failure to show any additive effect of saline and colloid when the salt deficit is replaced completely does not invalidate this conclusion. Obviously, when either form of treatment alone produces complete or almost complete restitution of cardiovascular function, further recovery, and hense demonstration of an additive effect, are physiologically impossible. Since beneficial effects of colloid solutions beyond those due to their salt content have been observed in a form of shock in which the loss of circulating protein is limited, and may be entirely absent, the implications of our findings are even more pertinent in other types of shock in which the loss of protein is not only more extensive, but prolonged as well.

\section{SUM MARY AND CONCLUSIONS}

1. In early salt-depletion shock replacement of the salt deficits by either 0.9 per cent or 5 per cent saline was followed by restoration of the plasma 
volume, the circulating plasma protein, and the circulatory dynamics to normal limits.

2. An identical degree of recovery, however, was observed following administration of small amounts of either serum or gelatin containing only sufficient salt to replace 11 to 36 per cent of the initial deficits.

3. Administration of small amounts of either low-salt colloid solutions, or of 0.9 per cent saline in amounts equivalent to only 17 to 43 per cent of the initial deficit, failed to improve the circulatory status beyond the degree observed to occur spontaneously in untreated animals.

4. Colloid-containing solutions can exert a beneficial effect on the circulation in salt-depletion shock clearly beyond that due to the sodium chloride which they contain.

5. Optimal therapy of all forms of shock should include not only the replacement of salt deficits present, but also the administration of colloidcontaining solutions.

\section{BIBLIOGRAPHY}

1. Elkinton, J. R., Danowski, T. S., and Winkler, Á. W., Hemodynamic changes in salt depletion and in dehydration. J. Clin. Invest. 1946, 25, 120.

2. Danowski, T. S., Winkler, A. W., and Elkinton, J. R., The treatment of shock due to salt depletion; comparison of the hemodynamic effects of isotonic saline, of hypertonic saline, and of isotonic glucose solutions. J. Clin. Invest., 1946, 25, 130.

3. Blalock, A., Principles of Surgical Care: Shock and Other Problems. C. V. Mosby Co., St. Louis, 1940.

4. Harkins, H. N., Recent advances in the study and management of traumatic shock. Surgery, 1941, 9, 231, 447, 607.

5. Wiggers, C. J., The present status of the shock problem. Physiol. Rev., 1942, 22, 74.

6. Moon, V. H., Shock and Related Capillary Phenemena. Oxford University Press, New York, 1938.

7. Blalock, A., Experimental shock: the cause of the low blood pressure produced by muscle injury. Arch. Surg., 1930, 20, 959.

8. Parsons, E., and Phemister, D. B., Haemorrhage and "shock" in traumatized limbs; an experimental study. Surg., Gynec., and Obst., 1930, 51, 196.

9. Beard, J. W., and Blalock, A., Experimental shock. VIII. The composition of the fluid that escapes from the blood stream after mild trauma to an extremity, after trauma to the intestines, and after burns. Arch. Surg., 1931, 22, 617.

10. Wiggers, C. J., The failure of transfusions in irreversible hemorrhagic shock. (A study of central venous pressures.) Am. J. Physiol., 1945, 144, 91.
11. Beard, J. W., and Blalock, A., Intravenous injections. A study of the composition of the blood during continuous trauma to the intestines when no fluid is injected and when fluid is injected continuously. J. Clin. Invest., 1932, 11, 249.

12. Neuwelt, F., Levinson, S. O., Olson, W. H., and Necheles, H., Further studies of hemorrhage and serum infusion. Surgery, 1940, 8, 644.

13. Dunphy, J. E., and Gibson, J. G., 2nd, Effect of replacement therapy in experimental shock. Surgery, 1941, 10, 108.

14. Moyer, C. A., Coller, F. A., Iob, V., Vaughn, H. H., and Marty, D., A study of the interrelationship of salt solutions, serum, and defibrinated blood in the treatment of severely scalded, anesthetized dogs. Ann. Surg., 1944, 120, 367.

15. Cournand, A., Noble, R. P., Breed, E. S., Lauson, H. D., Baldwin, E. de F., Pinchot, G. B., and Richards, D. W., Jr., Chemical, clinical, and immunological studies on the products of human plasma fractionation. VIII. Clinical use of concentrated human serum albumin in shock, and comparison with whole blood and with rapid saline infusion. J. Clin. Invest., 1944, 23, 491.

16. Warren, J. V., Stead, E. A., Jr., Merrill, A. J., and Brannon, E. S., Chemical, clinical, and immunological studies on the products of human plasma fractionation. IX. The treatment of shock with concentrated human serum albumin: a preliminary report. J. Clin. Invest., 1944, 23, 506.

17. Swingle, W. W., Remington, J. W., Kleinberg, W., Drill, V. A., and Eversole, W. J., An experimental study of the tourniquet as a method for inducing circulatory failure in the dog. Am. J. Physiol., 1942, 138, 156.

18. Rosenthal, S. M., Experimental chemotherapy of burns and shock. III. Effects of systemic therapy on early mortality. Pub. Health Rep., 1943, 58, 513.

19. Rosenthal, S. M., Experimental chemotherapy of burns and shock. IV. Production of traumatic shock in mice. V. Therapy with mouse serum and sodium salts. Pub. Health Rep., 1943, 58, 1429.

20. Fox, C. L., Jr., Oral sodium lactate in the treatment of burn shock. J. A. M. A., 1944, 124, 207.

21. Fox, C. L., Jr., and Keston, A. S., The mechanism of shock from burns and trauma traced with radiosodium. Surg., Gynec., and Obst., 1945, 80, 561.

22. Lowdon, A. G. R., McKail, R. A., Rae, S. L., Stewart, C. P., and Wilson, W. C., Changes in sodium and in other constituents of blood and extracellular fluids following scalds. J. Physiol., 1939, 96, 27P.

23. Darrow, D. C., and Yannet, H., Metabolic studies of the changes in body electrolyte and distribution of body water induced experimentally by deficit of extracellular electrolyte. J. Clin. Invest., 1936, 15, 419.

24. Warren, J. V., Merrill, A. J., and Stead, E. A., Jr., The rôle of the extracellular fluid in the maintenance of a normal plasma volume. J. Clin. Invest., 1943, 22, 635. 